Journal of Nepal Geological Society

Vol. 2, No. 1.,1982. 16-23

\title{
HIMALAYAN NAPPES IN AND ADJACENT TO CENTARAL NEPAL
}

A. H. G. Mitchell, A. N. Bhandary, B. M. Jnawali, D. P. Madhikermi. K. M. Amatya, P. P. Adhikari, R. R. Shakya, R. R. Sharma and S. M. Tamrakar.

HMG/UNDP Mineral Exploration Project, Post Box 1319, Lainchaur, Kathmandu, Nepal

\section{सा रांश}

मध्य नेपालको मूख्य मध्यवर्ति प्रघात क्षेत्र वरिपरि हालै गरिएको भौर्गभक नकसाले के देख्वाउंछ भने वेनिघाट स्लेट र यस माथि रहेका चट्टानहरू संभवतः नेप (Nappe) हुन् । यी नेपहुू भारतको कुमाउ ग्रुपमा पर्ने जुतोघ नेपसंग समान हुन सक्छन्। त्यस्तै ग्रामपिपल नेफेलिन सिएनाईटलाई ईण्डयन शिल्डको जग मान्यो भने तल्लो नत्रकोट ग्रुप पनि नेप हुन श्राउँछ। बेनिघाट, तल्लो नुवाकोट र काठमाण्डू नेपहरूको कुल विस्थापन २१० किलोमिटर भन्दा वढि हुन श्राउँछ जस्को मतलब भारतिय उपमहाद्वीप (Indian plate) को महाद्वीपीय भूपूष्ठ (Continental crust) दक्षिण तिव्वत तिर श्रन्तर प्रघातित (underthrust) भएको छ ।

\section{ABSTRACT}

Results of recent geological mapping in the region of the Main Central Thrust of central Nepal indicate that the Benighat Slates and overlying units are a nappe probably equivalent to the Jutogh Group of Kumaon. Interpretation of the Ampipal Nepheline Syenite as basement of the Indian Shield implies that the Lower Nawakot Group is also a nappe. Total displacement on the Benighat Nappe, the Lower Nawakot Nappe and the previously described Kathmandu Nappe exceeds $210 \mathrm{~km}$, indicating that continental crust of the Indian Plate has underthrust southern Tibet. South of the Transhimalayan magmatic arc, loss of the former arc-trench gap implies more than $100 \mathrm{~km}$ of northward overthrusting by upper crustal rocks of the Tethyan Himalayas.

\section{INTRODUCTION}

Central Nepal includes the main tectonic units of the Himalayas recognized throughout the Range south of the Indus-Tsangpo Suture (Figs. 1 and 3). These comprise, from south to north, the Siwalik terrigeneous sediments of Micocene to Pliocene age; the Lower Himalayas or midlands regions with a thick predominantly metasedimentary succession lying in tectonic contact with the Siwaliks along the Main Boundary Thrust; and the Higher Himalayas consisting of the Metamorphic Tibetan Slab or Central 


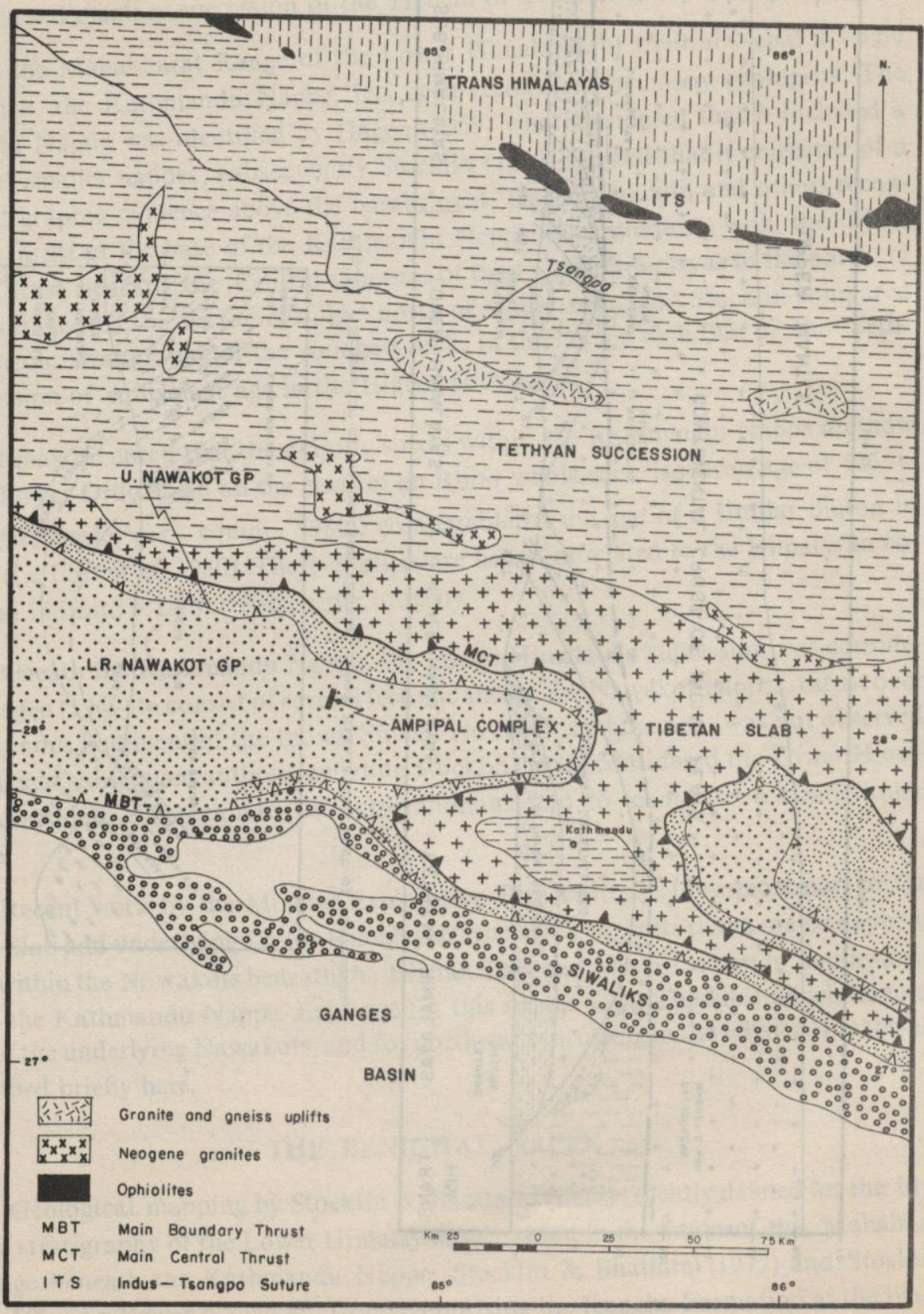

Fig. I Simplified geological map of Central Nepdl region, modified from Gansser (1977) 


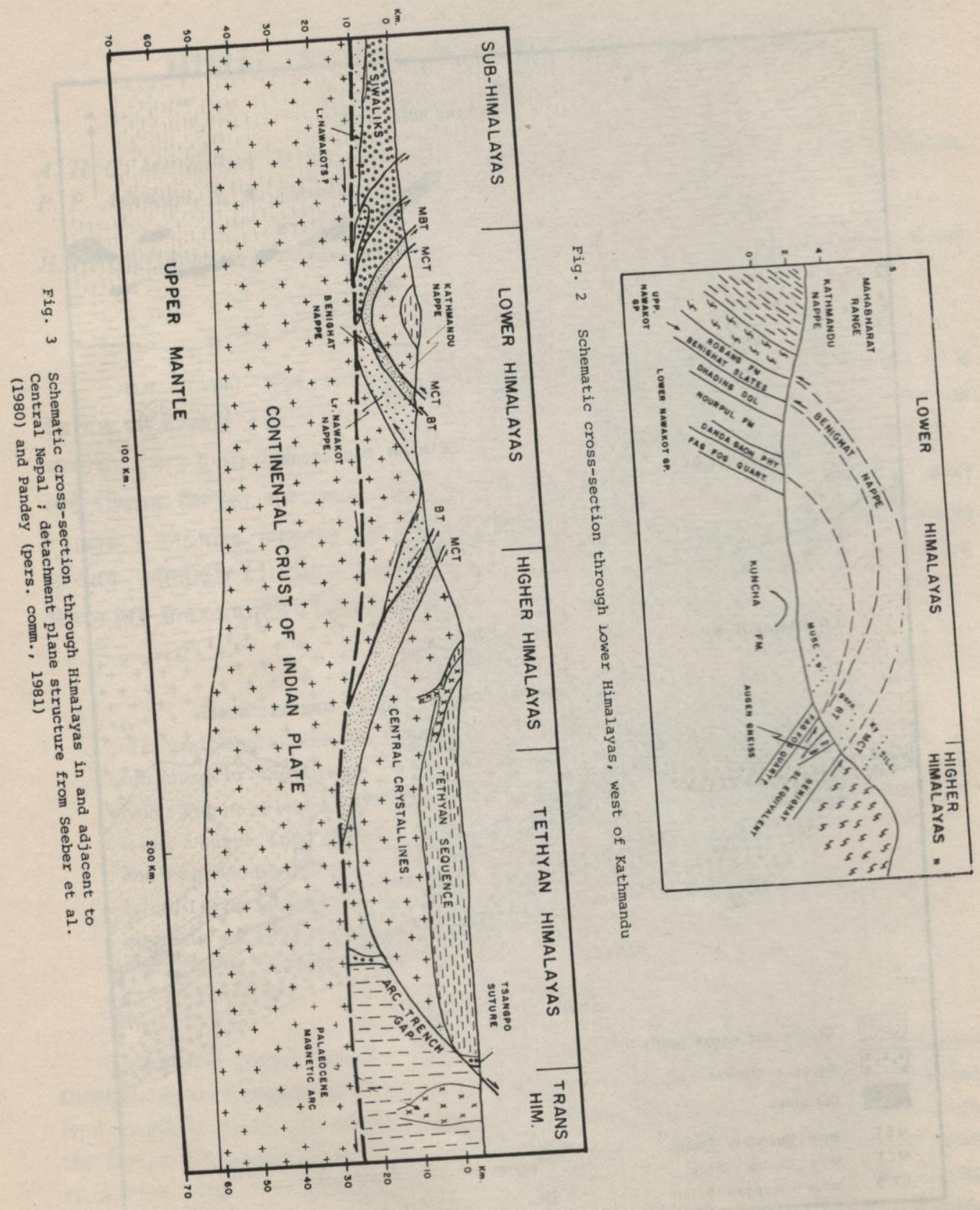


Gneisses at the base overlain without structural discontinuity by the Lower Palaeozoic to Mesozoic sedimentary succession of the Tibetan or Tethyan Himalayas.

In the Mahabharat Range of the Lower Himalayas of Central Nepal a single major nappe, the Kathmandu Nappe, has been recognized by many geologists. The Kathmandu Nappe was identified by Hagen (1969) who considered that it included a complex of smaller nappes; subsequently Stocklin (1980) showed that it consisted of a single stratigraphic sequence above the basal thrust. Hagen, Stocklin and others recognized the thrust at the base of the Kathmandu Nappe as continuous with the Main Central Thrust beneath the Central Gneisses of the Higher Himalayas to the north, to which it is linked by the 'tectonic bridge' north of Kathmandu, and Stocklin compared the Palaeozoic stratigraphy of the youngest rocks in the Nappe with that of the Tethyan succession of equivalent age in the Higher Himalayas.

It may be noted that the granitic sheets within the Kathmandu Nappe are now dated as Lower Ordovician on the basis of an $\mathrm{Rb} / \mathrm{Sr}$ whole rock isochron age of $486 \pm$ 10 my (Beckinsale, pers. comm., 1980), comparable to the age of a similar pluton in Pakistan (Le Fort et al, 1980). These granites are hence unrelated to the Himalayan collision and indicate a Lower Palaeozoic orogeny.

Beneath the Kathmandu Nappe, the Lower Himalayan succession was considered by Hagen (1969) to consist of several tectonic sheets, the Nawakot nappes, thrust over autochthenous basement of the Indian Shield. However the basement was not observed in Nepal, and subsequent authors including Stocklin (1980) considered the Lower Himalayan succession in this region to be autochthonous and to comprise a stratigraphic sequence.

Recent work by the Mineral Exploration Project in the lowermost part of the Tibetan Slab and underlying Lower Himalayan succession suggests that a major nappe is present within the Nawakots beneath the Tibetan Slab, and that it extends southwards beneath the Kathmandu Nappe. Evidence for this nappe, for the possibly allochthonous nature of the underlying Nawakots, and for northward thrusting in the Higher Himalayas, is described briefly here.

\section{THE BENIGHAT NAPPE}

Geological mapping by Stocklin \& Bhattarai (1977) recently defined for the first time the stratigraphy of the Lower Himalayan succession in the flanks of the Mahabharat Range beneath the Kathmandu Nappe. Stocklin \& Bhattarai (1977) and Stocklin (1980) defined a Lower Nawakot Group comprising the Kuncha Formation at the base, 
more or less equivalent to the Lower Midlands Formation of Pecher (1977), overlain by the sequence Fagfog Quartzite - Dandagaon Phyllites - Nourpul Formation - Dhading Dolomite (Fig. 2), broadly equivalent to the Lower Midland Group of French geologists. This succession was recognized as being of late Proterozoic age, with the probable exception of the Dhading Dolomite which was tentatively assigned to the Cambrian. Stocklin also recognized an overlying Upper Nawakot Group comprising the Benighat Slates, Malekhu Limestone and Robang Formation, considered to be of probable Permo-Carboniferous age and to rest unconformably on the Lower Nawakot Group

Recent geological mapping carried out during reconnaissance geochemical exploration north in the region of the Main Central Thrust has shown that the lowest exposed unit of the Lower Nawakot Group, the Kuncha Formation, is overlain to the north by a unit resembling the Fagfog Quartzite, but that the overlying units of the Group are absent (Fig. 2). Instead, the Fagfog Quartzite is overlain directly by a succession of graphitic phyllites, carbonates and minor amphibolites and local quartzite resembling the Benighat Slates of the Upper Nawakot Group. Northwest of Kathmandu this succession can be traced round the base of the gneisses which link the Central Gneisses or Tibetan Slab with the base of the Kathmandu Nappe (Fig. 1), and is physically continuous with the Benighat Slates mapped by Stocklin beneath the Kathmandu Nappe.

The contact between the Fagfog Quartzite overlying Benighat Slates beneath the Main Central Thrust is not well exposed. While Hashimoto et al. (1973) recognized a thrust more or less at the base of the Benighat Slates equivalent in this region, the absence of the upper part of the Lower Nawakot Group could alternatively be explained by erosion beneath the unconformity postulated by Stocklin (1980) at the base of the Benighat Slates. However, the lithology of the Benighat Slates and their equivalent to the north is closely comparable to that of the Jutogh Group in Himachal Pradesh in the western Himalayas. Moreover, the Benighat Slates also resemble the Lower Crystalline Nappe of Fuchs (1980) described from western Nepal, which underlies his Upper Crystalline Nappe or Central Gneisses. It therefore apears that the equivalent of the Benighat Slates beneath the Main Central Thrust and the Benighat Slates and cverlying units o, the Upper Nawakot Group beneath the Kathmandu Nappe comprise a single major nappe, hete termed the Benighat Nappe, with the Benighat Thrust at its base.

\section{STRATIGRAPHIC AND EMPLACEMENT AGES OF THE BENIGHAT NAPPE}

There is little direct evidence for the age of the rocks comprising the Benighat Nappe. The Jutogh Group in Himachal Pradesh is intruded by the Chaur Granite which has yielded an $1000 \mathrm{my} \mathrm{K} / \mathrm{Ar}$ age (Bhr rgava, 1980), suggesting a mid-Pıterozoic or 
older age for the Group and hence tor the Benighat Slates. In central Nepal part of the Ulleri Augen Gneiss of Le Fort \& Pecher (1974) and the probably equivalent Melung Augen Gneiss of Hashimoto et al. (1973) lie within and at the base of the gently dipping Benighat Slates equivalent south of the Main Central Thrust, and were interpreted by Le Fort \& Pecher, (1974) Pecher \& Le Fort (1977) as meta-volcanic rocks of probable Palaeozoic age. However, recent mapping suggests that the Gneiss, which is locally more than $1000 \mathrm{~m}$ thick, may be a metamorphosed granitic sheet intruding the Benighat succession, perhaps equivalent to the Chaur Granite; $\mathrm{Rb} / \mathrm{Sr}$ whole rock isochrons presently being determined on this Gneiss by the Institute of Geological Sciences, London, should yield a minimum age for the Benighat Slates.

The more or less parallel nature of the bases of the Benighat and Kathmandu Nappes suggests that the Benighat Nappe was also emplaced during the Himalayan orogeny. However, beneath the Main Central Thrust metamorphic grades increase upwards and northwards (Le Fort, 1975), from muscovite in the central part of the Kuncha Formation through biotite into garnet in the top of the formation and in the Fagfog Quartzite and lower part of the Benighat Slates equivalent. The grade continues to increase upwards without apparent break into local kyanite in the upper part of the Benighat Slates, immediately beneath the kyanite-bearing gneisses above the Main Central Thrust. This suggests that the Benighat Nappe was emplaced before the advance of the Kathmandu Nappe and Tibetan Slab and that the reverse metamorphic isograds resulted from subsequent downward conductive heating from the overriding Tibetan Slab. Emplacement of the Benighat Nappe presumably post-dated early Eocene collission of Indian with Asia, and probably took place in the Oligocene shortly before the Oligocene or early Micocene emplacement of the Kathmandu Nappe.

The original stratigraphic position of the Upper Nawakot Group comprising the Benighat Nappe is uncertain, as similar rocks are absent in both the Tethyan succession of the Higher Himalayas and the Lower Himalayas successions. It is tentatively considered here to have formed a part of the Lower Himalayas succession, possibly above the Dhading Dolomite in a stratigraphic position similar to that of its present structural position in the Mahabharat Range. However, since the Benighat Nappe lies in a structurally lower position towards its root zone in the north, it is equally possible that the Benighat Slates originated from a stratigraphic position beneath the Kuncha Formation.

\section{THE LOWER NAWAKOT NAPPE}

Support for Hagen's suggestion that the succession, now known as the Lower Nawakot Group is allochthonous depends on identification of basement rocks of the 
Indian Shield structurally beneath the Kuncha Formation. The only known occurre of possible basement in Nepal is the Ampipal nepheline sysnite body with minor asso ted ultrabasic rocks lying some $80 \mathrm{~km}$ west of Kathmandu. The syenite is a NI trending gneissic body about $8 \mathrm{~km}$ in length, exposed at the base of the Kuncha For tion within the core of an anticline.

The nature of the contact between the syenite gneiss and Kuncha Formation obscure. The body has been interpreted as a dyke or possibly sill intruded into the $\mathrm{K}$ cha metagreywackes in the Tertiary (Lasserre, 1977). However, there is no evidence contact metamorphism or alteration of the immediately adjacent 'host' rocks, and strongly gneissic texture of the syenite suggests that it is more highly metamorpho than the adjacent biotite-grade phyllites at its southern end. The contact cannot be unconformity because the syenite truncates the bedding of the Kuncha Format especially towards the north.

The possibility of a thrust between the Kuncha Formation and Ampit syenite was suggested considering the similarity of structural position of the syenite that of the Permo-Carboniferous Gondwana Formation in Sikkim (D. Dhoundial, pers. comm. 1981). The Gondwana in Sikkim occupy a tectonic wind surrounded largely by the Daling Formation, the equivalent of the Kuncha Formati and locally (Raina \& Srivastava, 1980) by the Buxa Formation, equivalent to the No puls and Dhading Dolomite of the Lower Nawakots; the Dalings in turn are alm surrounded by overthrust Central Crystallines. Since the Gondwanas to the south northern Peninsular India lie on Precambrian rocks, it may be inferred that rocks the Precambrian Shield also underlie the Gondwanas (in Sikkim. By analogy, nepheline syenite of Ampipal can be interpreted as Indian Shield rocks from which overlying Gondwanas have been removed either tectonically or by pre-thrusti erosion.

\section{NORTH-DIRECTED THRUSTS IN THE TSANGPO SUTURE ZONE}

North of the Higher Himalayas, the granodioritic rocks of the Transhimalay magmatic arc on the former overriding plate lie within a few kilometres of the ophiol rocks of the 'suture', and the 100 to $150 \mathrm{~km}$ wide belt comprising the precollision trenchgap characteristic of all arc systems is absent. By analogy with the Taiwan a Timor collision belts, the loss of this belt can be explained by overriding of the up crustal rocks of the Tibetan plate by the Indian plate, in a manner analogous to, but volving a thinner crustal layer than, that suggested by Audley-Charles et al., (1980). E 
placement of this northward-directed thrust sheet or nappe can explain the northwardfacing folds found in parts of the Higher Himalays, and the southward dip of the 'suture zone' rocks in Ladakh and elsewhere, as well as the juxtaposition of the India 'Tethyan' sequence with the Transhimalayan magmatic arc. Depending on the position of the south-dipping thrust when it was initiated, the upper crust of the arc-trench gap may have been either overthrust southwards onto the Tethyan succession and eroded, or more probably, under-thrust beneath the Tethyan succession (Fig. 3).

\section{CRUSTAL SHORTENING AND UNDERTHRUSTING BENEATH TIBET}

The displacement on the Main Central Thrust is $80 \mathrm{~km}$, and the measured displacement on the Benighat Thrust, assuming the Benighat Nappe to have originated from beneath the Kuncha Formation, is also about $80 \mathrm{~km}$. If the Lower Nawakot Group is allochthonous with respect to the Ampipal Syenite, displacement of the Group is at least $50 \mathrm{~km}$. These are all minimum displacements, since the gentle dip of the Main Central Thrust and Benighat Thrust indicate that the Benighat and Lower Nawakot Nappes extend at depth well to the north of the Main Central Thrust outcrop. Moreover, seismic activity in Nepal can best be explained by movement on a detachment plane (Pandey, 1981 pers. comm.) similar to that inferred by Seeber et al (1980) in the Pakistan Himalayas; this detachment plane extends from far to the south of the Siwaliks to the Tethyan Himalayas, a distance of more than $300 \mathrm{~km}$, and it is unlikely that displacement is less than a few tens of kilometres. The total crustal shortening in the Himalayas isthus at least $210 \mathrm{~km}$ and very probably more than $300 \mathrm{~km}$. As the Main Boundary Fault lies only 220 kmsouth of the Tsangpo Suture zone, the Indian continental crust must have underthrust the Transihimalayas and could extend northwards many hundreds of kilometres beneath the Tibetan Plateau, as suggested by Powell and Conaghan (1973) and in contrast to the crustal thickening model of Dewey \& Burke (1973).

\section{CONCLUSION}

The Lower Himalayas of Central Nepal consist of atleast two and very probably three major nappes with a total southward displacement of at least $300 \mathrm{~km}$, implying that continental crust of the Indian plate has underthrust the Transhimalayas north of the suture. South of the Transhimalayan magmatic arc, rocks of the arc-trench gap are probably thrust southwards at least $100 \mathrm{~km}$ beneath the overlying Tethyan sequence of the Indian plate. 


\section{ACKNOWLEDGEMENTS}

We thank the Administrator of the Mineral Exploration Development Board of Nepal for permission to publish this Paper.

\section{REFERENCES}

Audley-Charles, M. G., Latreille, M. and Nayoan, G.A.S., 1980. Comparison of orogenic features of the Tethyan mountain belt from the Himalayas to the East Asian arcs. Mem. Bur. Rech. Geol. Min. 115, 155-165.

Bhargava, O. N., 1980. Outline of the stratigraphy of Eastern Himachal Pradesh, with special reference to the Jutogh Group. in Stratigraphy and correlations of Lower Himalayan Formations (K. S. Valdiya and S. B. Bhatia, eds.), 117-125. Hindustan Publ. Co., Delhi.

Dewey, J. F. and Burke, K. C. A., 1973. Tibetan, Variscan and Precambrian basement reactivation: products of continental collision. Jour. Geol. 81, 683-692.

Fuch, G., 1980. The Lesser Himalayan geology of West Nepal and its regional importance. In Stratigraphy and correlation of Lesser Himalayan formations (K. S. Valdiya and S. B. Bhatia, eds.), 163-175. Hindustan Publ. Co., Delhi.

Gansser, A., 1964. Geology of the Himalayas. Inter science publishers, London, 289pp.

Gansser, A., 1977. The great suture zone betwee Himalaya and Tibet, a preliminary account. In Himalaya, Sciences de la Terre, 181-191. Coll. Internat. CNRS No. 268, Paris.

Hagen, T., 1969. Report on the geological survey of Nepal, Vol. 1 (preliminary reconnaissance). Denkschr. Schweiz, naturf. Ges. Bd. 6, AC1.

Hashimoto, S. et al (eds.), 1973. Geology of the Nepal Himalayas. Tokoyo, 292 p.

Lasserre, J. L., 1977. Amphibolites and alkaline gneisses in the midland formations of Nepal; petrography, geochemistry-geodynamic involvements. In Himalaya Sciences de la Terre, 213-236, Coll. Internat. CNRS No. 268, Paris.

Le Fort, P., 1975. Himalayas ; the collided range. Present knowledge of the continental arc. Amer. J. Sci. $275,1-44$.

Le Fort, P. and Pecher, A., 1974. Les gneiss oeilles du moyen pays nepalias: un ensemble volcano-sedimentaire acide d'age Paleogoique ou plus ancien en Himalaya. C. R Acad. Sci. Paris, t. 378,
3283-3286.

Le Fort, P., Debon, F. and Sonet, J., 1980. The 'Lower Himalayan' cordierite granite belt typology and age of the pluton of Manserah (Pakistan). Proc. Intern. Commit. Grp. 6, Mtg. Peshawar, 1979; Spec. Issue, Geol. Bull. Univ. Peshwar, 13, 23-29.

Pecher, A., 1977. Geology of the Nepal Himalaya: deformation and petrography in the Main Central Thrust Zone. In: Himalaya: Sciences de la Terre, 301-318. Coll. Internat. CNRS No. 268, Paris. 
Jr. Nep. Geol. Soc.

Pecher, A. and Le Fort, P. 1977. Origin and significance of the Lower Himalayan augen gneisses. In : Himalaya Sciences de la Terre, 319-330. Coll. Internat, CNRS no. 268. Paris.

Powe 1l, C. Mc. A. and Conaghan, P. J., 1973. Plate tectonics and the Himalayas. Earth Planet. Sci. Letts. 20, 1-12.

Raina, V. K. and Srivastava, B. S., 1980. A reappraisal of the geology of the Sikkim Lesser Himalaya. In Stratigraphy and Correlations of Lesser Himalayan Formations (K. S. Valdiya and S. B. Bhatia, eds), 201-210. Hindustan Publ. Co., Delhi.

Seeber, L., Quittmeyer R. and Armbruster, J., 1980. Seismotectonics of Pakistan: a review of results from network-data and implications for Central Himalaya. In Structural Geology of the Himalaya (P. S. Saklani, ed), 361-391. Today and Tomorrow's Printers and Publishers, Delhi.

Stocklin, J., 1980. Geology of Nepal and its regional frame. J. Geol. Soc. Lond. 137, 1-34.

Stocklin, J. and Bhattarai, K., 1977. Geology of Kathmandu Area and Central Mahabharat Range, Nepal Himalaya. Tech. Rep. PG/11/77, HMG/UNDP Min. Expl. Project, Kathmandu (unpub). 